\title{
The Political Economy of Industrial Policy: A Comparative Study of the Textiles Industry in Pakistan
}

\section{Matthew McCartney*}

\begin{abstract}
The textiles industry in Pakistan has failed to fulfill its "historical mission," whether judged in terms of promoting rapid and sustained economic growth, reducing poverty, or providing employment to young women and so promoting wider social transformation. This paper makes a case for a particular and targeted form of industrial policy that would help the textiles sector learn and upgrade. It argues that those factors commonly seen as constraints to industrial policy - the "China effect," the global rules of globalization, global value chains, and the problems of energy and education in Pakistan-do need careful consideration, but they are not insurmountable obstacles to industrial upgrading. The key market failure is the risk and uncertainty associated with acquiring and learning to use new technology. The paper explores a number of policy options, reviewing the lessons that cannot be learned from the Republic of Korea and India and one that can from Bangladesh. The latter shows that rapid and sustainable export growth in textiles can be achieved, even in an economy with a weak, corrupt, and unstable form of governance.
\end{abstract}

Keywords: Pakistan, Korea, Bangladesh, textiles, industrial policy, technological change, upgrading.

JEL classification: L50, O40.

\section{Introduction}

It is often assumed, but much less often explained, that being selfsufficient in raw cotton is good for the textiles industry in Pakistan. It may be true that Pakistan, among only a few other developing countries, has "a fully developed textile value chain from fiber to fabric to garment exports and a low import intensity of only 1\%" (Tewari, 2005). Yes, this does mean that the country's textiles industry has its cotton nearby but also means that the industry is tied to a local cotton monopoly. In Pakistan, cotton yields are much lower than among other producers and quality has long remained

* Director of the Contemporary South Asian Studies Programme and Associate Professor, School of Interdisciplinary Area Studies, University of Oxford. 
below international standards. The textiles industry in nineteenth-century Britain, by comparison, was a leading sector in a much wider process of industrialization and Britain's cotton was always imported from the most competitive supplier. When the prices of US cotton increased during the 1860s Civil War, Britain switched suppliers to colonial India.

The domestic value chain is not just a source of inputs, it is also a source of vested interests or what Amjad (2005) calls "cottonomics." This, he argues, is a story of the conflict between the textile industrialists who want cheap raw cotton and the landlords and farmers who want higher prices paid by domestic users or at least the freedom to export at higher world prices. During the 1990s, argues Amjad, "this classic battle was fought between the industrial classes represented by the Nawaz Sharif government and the cotton-producing belt of southern Punjab and Sindh represented by Benazir [Bhutto]'s People's Party. Who got a better deal depended very much on which party was in power" $(2005$, p. 389).

For whatever reasons-and many have been suggested-the textiles industry in Pakistan has not (yet) fulfilled its historical mission. Whether in nineteenth-century Britain, 1920s Japan, 1960s Republic of Korea, or 1980s China, the textiles industry functioned as a "lead sector." Textiles in these examples were associated with a number of developments: (i) the rapid growth of exports, (ii) being a conduit for the introduction of new technology, (iii) drawing low-skilled labor into formal sector employment and so reducing poverty, (iv) facilitating the structural change to an urban-industrial economy, (v) creating jobs for young women and so promoting female mobility empowerment, and (vi) wider indirect developmentally positive impacts on female education and children's health. While acknowledging that the reasons for the sector's failure are manifold and the resulting policy conclusions potentially overwhelming, this paper makes a case for market failures in technological learning as being a "key reason" for this historical failure in Pakistan. This reason is "key" in the very specific sense that targeted policy interventions to reduce this market failure are feasible and lowcost, and would require only a manageable amount of political and administrative effort to implement.

The paper is organized as follows: Section 2 outlines a brief history of the textiles industry in Pakistan. Section 3 critically reviews factors that are currently seen to constrain growth and upgrading in Pakistan's textiles sector. Section 4 explores the link between technology and learning in the textiles sector. It starts by problematizing a typical form of economic "analysis" in Pakistan: that of compiling long lists of 
problems and advocating their solutions. It then focuses on a key market failure, that of technology acquisition and learning, and finally part explores some potential solutions that are both feasible and draw useful lessons from elsewhere. Section 5 concludes the study.

\section{A History of the Textiles Sector}

This section reviews the "historical failure" of the textiles sector in Pakistan after independence, from its promising start in the 1960s to the long era of stagnation after 1970.

In 1950, Pakistan was a predominantly agrarian economy: agriculture comprised 53 percent and manufacturing only 6.4 percent of the GDP (McCartney, 2011, p. 42). The industry that did exist was smallscale and mainly agro-based, such as flour mills, rice mills, sugar factories, and cotton-ginning factories. East Pakistan was the world's biggest supplier of jute but had no jute mills; its output was exported to mills in Calcutta. West Pakistan was a major supplier of raw cotton but had inherited only 14 of the near 400 cotton textile mills of British India. Raw hides suitable for the production of leather were exported to tanneries in Madras and Kanpur. East Bengal produced bamboo pulp, the North-West Frontier Province (now Khyber Pakhtunkhwa) raw wool, and Chitral mineral oil and antimony, which were exported to the paper mills of West Bengal and the wool mills of eastern Punjab, Uttar Pradesh, and Bombay (Talha, 2000, p. 153).

Rapid industrial growth (from a low base) during the 1950s saw Pakistan achieve domestic self-sufficiency in many consumer goods industries. Over the 1960s, these sectors began to export. The process was helped by a number of deliberate policies. The Export Bonus Scheme introduced in January 1959, for instance, provided an incentive to increase manufactured exports. There was also a diversification of exports away from traditional primary exports to textiles (Lewis, 1970, p. 120). The government acted to channel resources to emerging industries.

In the early 1960s, the public sector development banks-the Pakistan Industrial Credit and Investment Corporation (PICIC) and the Industrial Development Bank of Pakistan-provided almost 70 percent of the foreign exchange component of total investment projects sanctioned. The projects of these institutions accounted for about 65 percent of the total investment sanctioned (Amjad, 1982, p. 56). Cotton and jute textiles and sugar refining were the most important areas in which PICIC operated 
during this time (Lewis, 1970, p. 103). The Pakistan Industrial Development Corporation (PIDC) was established in the 1950s to pioneer investments in sectors that, although important, the private sector was unwilling to enter.

As time elapsed, many of these projects were sold to the private sector and played a crucial role in establishing some of the major industrial houses. In West Pakistan, the Saigols bought the Jauharabad Sugar Mill and the Dawoods took over the Burewala Textile Mills from the PIDC (Amjad, 1983, p. 237). The data show that this process of industrial diversification in the 1960s was relatively efficient. There was also rapid productivity growth in manufacturing, including textiles (Cheema, 1978, p. 48; Srinivasan, 2005; Zaidi, 2005, p. 102; Kemal, Din, \& Qadir, 2006, p. 306). Unfortunately, this favorable pattern of growth did not continue.

The textiles sector (and industry more generally) performed poorly from the 1970s onward. After an encouraging start to economic diversification in the 1960s, Pakistan remained stuck in the following decades as an exporter of low-value raw cotton and intermediate textile products. The share of cotton yarn and cotton cloth in export earnings remained at about two thirds of the total with raw cotton accounting for another quarter from 1970 to the mid-1990s (Khan, 1998, p. 602). In 2012/13, the readymade garments (RMG) subsector provided the highest value-added of all textiles, but constituted only US $\$ 1.3$ billion (about 10 percent) of textile exports. External constraints were not obviously responsible. During the 1990s, Pakistan's textile exports were not constrained by trade protection in developed countries. In 1993, quota utilization in certain categories for the major European Union (EU) countries was as low as 20 percent, and for the US, 28 percent (Khan, 1998).

There were real costs as a consequence of this failure to upgrade. High-technology products tend to have a more income-elastic demand and so, offer potential for more rapid growth of output and exports. Such products also offer greater potential for learning because there is more scope for applying new scientific knowledge and so, larger spillover effects in terms of creating new skills and learning. Simpler technologies are vulnerable to being replaced by new technological change and entry by lower-wage competitors. There is strong empirical evidence to support these arguments. Between 1985 and 1998, world exports of primary products grew by 3.4 percent per annum, low-technology manufactured exports by 9.7 percent, and high-technology manufactures by 13.1 percent (Lall, 2000, p. 344). 
As a result of these differential growth rates, there were corresponding changes in the structure of world trade. The share of resource-based exports fell from 23.7 percent of world exports in 1985 to 17.3 percent in 1998. Low-technology and medium-technology exports remained stable (at 18.6 and 18.8 percent, and 40.9 and 38.9 percent, respectively), while the share of high-technology exports increased (from 16.8 to 25.1 percent) (Lall, 2000, p. 351). Participation in this process of upgrading exports was characteristic of many successful developing country growth stories. Between 1981 and 2000, the share of developing countries in those high-technology exports increased from 9.2 to 32.3 percent (Lall \& Weiss, 2004, p. 17). In this, the failure of Pakistan is evident: its share of low-technology exports in total exports from Pakistan increased from 54 percent in 1985 to 76 percent in 2002 (Lall \& Weiss, 2004, p. 30).

More evidence on the technological failure of Pakistan is available at the industry level. Total factor productivity growth in the manufacturing sector slowed down from the 1990s onward (Mahmood \& Siddiqui, 2000; Pasha, Ghaus-Pasha, \& Hyder, 2002; Ara, 2004). An indirect indicator of technology relevant to export structure and competitiveness is the number of ISO 9000 certificates awarded at the national level. These certificates relate to management quality rather than technical effort alone and cover all activities, not just manufacturing. The number of such certificates in Pakistan increased from 1 in 1994 to 795 in 2002; in India, from 328 to 8,110; in China, from 150 to 75,755; and in Thailand, from 24 to 4,556 (Lall \& Weiss, 2004, p. 59).

In more recent years, the textiles sector has continued to perform poorly. Exports from Pakistan of all textiles increased from US\$ 11 billion in 2006/07 to US\$ 12.5 billion in 2011/12, although about a fluctuating rather than rising trend. Pakistan has also missed the rapid growth in world markets. World trade in textiles and clothing increased from US\$ 157 billion in 2000 to US\$ 250.7 billion in 2010, while Pakistan's share remained at 2 percent or less, showing no sign of a trend increase. The textiles sector experienced growth of less than 1 percent per annum in $2010 / 11,2011 / 12$, and 2012/13. The share of textiles in total exports fell from 65 to 53 percent.

Today, Pakistan's textile and clothing sector accounts for 46 percent of total manufacturing, 38 percent of the total manufacturing labor force, and 8 percent of GDP. Some have found causes for recent optimism. In November 2012, the EU announced a duty waiver on 75 products, which has increased market access for textile exporters. The 
media made bold forecasts: The News predicted in January 2014 that this would see "textile exports likely to rise by US\$ 3 billion." This is certainly good news, but a one-off boost to market access is not likely to generate sustainable growth over the longer term.

A telling example is that of the African Growth and Opportunity (AGOA) Act of the early 2000s. This act gave many exporters in Africa duty-free access to the US market. Between 1999 and 2004, clothing exports grew from virtually nothing to US\$ 495 million in Lesotho, US\$ 333 million in Kenya, and US\$ 205 million in Swaziland. In the mid-2000s, the preferential treatment for Africa was removed and its exporters competed in the US market on more equal terms with other countries. The value of sub-Saharan African clothing exports to the US dropped by 26 percent during 2004-06, including 26 percent from Madagascar, 24 percent from Swaziland, 53 percent from South Africa, and 48 percent from Mauritius (Kaplinsky \& Morris, 2008). Over the same period, the value of China's clothing and textile exports to the US increased by 84 percent and in the major products exported by AGOA, the value of Chinese exports rose by 161 percent.

\section{Constraints on Textile Exports from Pakistan}

This section reviews various constraints to upgrading technology as part of a policy effort to boost textile exports from Pakistan. These are the "China effect," the global rules of globalization, global value chains, and the country's energy and education crises.

\subsection{The China Effect}

The accession of China to the World Trade Organization (WTO) in the early 2000s had two effects. First, the country was forced to reduce trade protection and open its domestic market to foreign imports. Second, it gained easier access to the markets of other member countries. The impact was significant: in 2002, the first year of accession, China reduced tariff rates on more than 5,300 commodities and its general tariff level to 12 percent (Agrawal \& Sahoo, 2003). Many have argued the net "China effect" will likely be negative for exporters such as Pakistan. Chinese exports in sectors such as textiles, garments, leather, and leather products compete directly with Pakistani exports-a negative competition effect. The main commodities imported by China, such as machinery, minerals and mineral products, iron and steel, and organic chemicals, are not principal exports of Pakistan-an absent market access effect. 
The impact was real. With the later liberalization of global textiles trade and the abolition of the Multi-Fiber Agreement (MFA) in 2005, EU imports of textiles and clothing (in value terms) changed by -7 percent from Bangladesh, -17 percent from Pakistan, -35 percent from the Philippines, and +35 percent from China. The latter's export volumes increased by 50 percent in the first half of 2005 and global prices fell sharply-for cotton trousers, skirts, and sweaters, by almost 50 percent (Ananthakrishnan \& Jain-Chandra, 2005, p. 9).

Collier (2007) is pessimistic about any country outside Asia surviving this competitive onslaught. The poorest developing countries, he argues, will have to wait a long time until development in Asia creates a wage gap between those countries and the world's poorest countries similar to the massive gap between Asia and the developed world in 1980. This concern is overstated for Pakistan where the wage gap already exists. Comparative estimates of labor costs in textiles show them to be consistently lower in Pakistan than in China and other competitors. In 2000, for example, the average hourly wage (US\$) was 1.8 in Mexico, 0.9 in China, 0.7 in India, and only 0.2 in Pakistan and Bangladesh (Tewari, 2005, p. 28).

Another estimate, this time of "total textile industry operator costs" per hour (US\$) in 2000, was 1.18 in Thailand, 1.13 in Malaysia, 0.69 in China, 0.58 in India, and 0.37 in Pakistan. Only Indonesia at 0.32 was lower than Pakistan (Palpacuer, Gibbon, \& Thomsen, 2005, p. 416). A more recent, if more limited, estimate showed the hourly wage to be very low in Pakistan (US\$ 0.55) and in Bangladesh (US\$ 0.32) (Nathan Associates, 2009). Between 1999 and 2007, real wage growth was only about 1 percent per annum in Pakistan and 13 percent in China (International Labour Organization, 2012).

Collier would retort that only a small share of the cost of laborintensive goods comprises wages (about 16 percent according to one estimate). This implies that, if wages among the poorest developing countries were only one sixteenth of those in Asia, this would yield only a 15 percent cost advantage. For a fuller picture of costs in Pakistan, we do need to consider other costs, such as transport, law enforcement, corruption, electricity, and the availability of skilled labor. There is more extensive comparative cost evidence available. The rather detailed Table 1 below tries to quantify all the costs going into making a simple man's Tshirt. Notably, the fabric cost per kilogram (locally sourced) in Pakistan at US\$ 2.89 per $\mathrm{kg}$ is significantly lower than the US\$ 3.37 in Bangladesh and Cambodia, both of which source fabric from China. Overall, the total 
cost of producing a man's T-shirt in Pakistan is 7 percent less than in Bangladesh and 19 percent less than in China.

Table 1: T-shirt production cost estimates

\begin{tabular}{|c|c|c|c|c|c|c|}
\hline $\begin{array}{l}\text { Garment making } \\
\text { up by country }\end{array}$ & India & India & China & Pakistan & Bangladesh & Cambodia \\
\hline Fabric source & India & China & China & Pakistan & China & China \\
\hline \multicolumn{7}{|l|}{ Main fabric } \\
\hline $\begin{array}{l}\text { Fabric cost per kg } \\
\text { (US\$) }\end{array}$ & 3.019 & 3.336 & 3.336 & 2.894 & 3.336 & 3.336 \\
\hline $\begin{array}{l}\text { Fabric shipping cost } \\
\text { per kg (US\$) }\end{array}$ & 0.000 & 0.069 & 0.000 & 0.000 & 0.060 & 0.069 \\
\hline $\begin{array}{l}\text { Fabric use per } \\
\text { garment }(\mathrm{kg})\end{array}$ & 0.235 & 0.235 & 0.235 & 0.235 & 0.235 & 0.235 \\
\hline $\begin{array}{l}\text { Fabric waste (short } \\
\text { pieces, end of rolls, } \\
\text { faults) in } \%\end{array}$ & 5.000 & 5.000 & 5.000 & 5.000 & 5.000 & 5.000 \\
\hline $\begin{array}{l}\text { Main fabric cost per } \\
\text { garment (US\$) }\end{array}$ & 0.710 & 0.801 & 0.784 & 0.680 & 0.798 & 0.801 \\
\hline \multicolumn{7}{|c|}{ Trim cost per garment (US\$) } \\
\hline Thread & 0.045 & 0.45 & 0.045 & 0.045 & 0.045 & 0.045 \\
\hline Labels, tags & 0.037 & 0.037 & 0.037 & 0.037 & 0.037 & 0.037 \\
\hline \multicolumn{7}{|c|}{ Packaging per garment (US\$) } \\
\hline Plastic poly bag & 0.018 & 0.018 & 0.018 & 0.018 & 0.018 & 0.018 \\
\hline $\begin{array}{l}\text { Cardboard } \\
\text { box/carton }\end{array}$ & 0.06 & 0.06 & 0.06 & 0.06 & 0.06 & 0.06 \\
\hline $\begin{array}{l}\text { Total materials cost } \\
\text { per garment }\end{array}$ & 0.870 & 0.961 & 0.944 & 0.84 & 0.958 & 0.961 \\
\hline $\begin{array}{l}\text { Labor-hour US\$ cost } \\
\text { in making up }\end{array}$ & 0.830 & 0.83 & 1.44 & 0.55 & 0.32 & 0.335 \\
\hline $\begin{array}{l}\text { Standard minutes } \\
\text { per garment cut, } \\
\text { make, trim, finish }\end{array}$ & 6.120 & 6.12 & 6.12 & 6.12 & 6.12 & 6.12 \\
\hline $\begin{array}{l}\text { Efficiency } \\
\text { adjustment }\end{array}$ & 25.00 & 25.00 & 15.00 & 30.00 & 50.00 & 70.00 \\
\hline $\begin{array}{l}\text { Labor cost per } \\
\text { garment (US\$) }\end{array}$ & 0.106 & 0.106 & 0.169 & 0.073 & 0.049 & 0.058 \\
\hline $\begin{array}{l}\text { Reject garments } \\
(3 \%)\end{array}$ & 0.029 & 0.032 & 0.033 & 0.027 & 0.03 & 0.031 \\
\hline $\begin{array}{l}\text { Manufacturing } \\
\text { overhead per } \\
\text { garment }(25 \% \text { on } \\
\text { labor) (US\$) }\end{array}$ & 0.026 & 0.026 & 0.042 & 0.018 & 0.012 & 0.015 \\
\hline $\begin{array}{l}\text { Inclusive of } \\
\text { electricity, rent, } \\
\text { indirect labor }\end{array}$ & & & & & & \\
\hline
\end{tabular}




\begin{tabular}{|c|c|c|c|c|c|c|}
\hline $\begin{array}{l}\text { Garment making } \\
\text { up by country }\end{array}$ & India & India & China & Pakistan & Bangladesh & Cambodia \\
\hline $\begin{array}{l}\text { Sales and } \\
\text { administration costs } \\
(10 \% \text { on labor }) \\
\end{array}$ & 0.011 & 0.011 & 0.017 & 0.007 & 0.005 & 0.006 \\
\hline \multicolumn{7}{|c|}{ Total cost per garment (fabric, labor, overhead) in US\$ } \\
\hline $\begin{array}{l}\text { Sales and } \\
\text { administration }\end{array}$ & 1.042 & 1.136 & 1.206 & 0.966 & 1.055 & 1.070 \\
\hline $\begin{array}{l}\text { Agent fees per } \\
\text { garment }(4 \% \text { on } \\
\text { total cost) }\end{array}$ & 0.042 & 0.045 & 0.048 & 0.039 & 0.042 & 0.043 \\
\hline $\begin{array}{l}\text { Factory gate cost per } \\
\text { garment }\end{array}$ & 1.084 & 1.181 & 1.254 & 1.005 & 1.097 & 1.112 \\
\hline \multicolumn{7}{|c|}{ Shipping and insurance to Long Beach, CA (TEU) } \\
\hline $\begin{array}{l}\text { Land transport cost } \\
\text { to port (US\$) }\end{array}$ & 400 & 400 & 470 & 300 & 250 & 600 \\
\hline $\begin{array}{l}\text { Ocean freight from } \\
X \text { to Long Beach }\end{array}$ & Mumbai & Mumbai & Shanghai & Karachi & Dhaka & $\begin{array}{c}\text { Sihanoukvil } \\
\text { le }\end{array}$ \\
\hline $\begin{array}{l}\text { Ocean transport cost } \\
\text { per container incl. } \\
\text { insurance (US\$) }\end{array}$ & 2,100 & 2,100 & 1,800 & 2,000 & 1,900 & 1,900 \\
\hline Units per container & 18,000 & 18,000 & 18,000 & 18,000 & 18,000 & 18,000 \\
\hline $\begin{array}{l}\text { Transport and } \\
\text { insurance cost per } \\
\text { garment (US\$) }\end{array}$ & 0.139 & 0.139 & 0.126 & 0.128 & 0.119 & 0.139 \\
\hline $\begin{array}{l}\text { Total cost per } \\
\text { garment including } \\
\text { c.i.f. (US\$) }\end{array}$ & 1.223 & 1.32 & 1.38 & 1.133 & 1.216 & 1.251 \\
\hline $\begin{array}{l}\text { Tariff \% (import } \\
\text { duty to US) }\end{array}$ & 16.1 & 16.1 & 16.1 & 16.1 & 16.1 & 16.1 \\
\hline $\begin{array}{l}\text { Tariff per garment } \\
\text { (US\$) }\end{array}$ & 0.197 & 0.212 & 0.222 & 0.182 & 0.196 & 0.201 \\
\hline $\begin{array}{l}\text { Quota cost per } \\
\text { garment (US\$) }\end{array}$ & 0.000 & 0.000 & 0.000 & 0.000 & 0.000 & 0.000 \\
\hline VAT percentage & 12.50 & 12.50 & 17.00 & 15.00 & 15.00 & 10.00 \\
\hline VAT applied (US\$) & 0.150 & 0.160 & 0.000 & 0.000 & 0.180 & 0.000 \\
\hline $\begin{array}{l}\text { Cost per garment } \\
\text { (tariff, quota, and } \\
\text { VAT) (US\$) }\end{array}$ & 0.350 & 0.377 & 0.222 & 0.182 & 0.378 & 0.201 \\
\hline Full landed cost per gar & nent duty $p$ & $d(U S \$)$ & & & & \\
\hline
\end{tabular}

Source: Nathan Associates (2009, pp. 1-2).

\subsection{The Global Rules of Globalization}

Chang (2003) argues that the International Monetary Fund (IMF), World Bank, and WTO have pushed a "good governance" agenda onto developing countries, which consists of conservative macroeconomic policies, the liberalization of international investment and trade, 
privatization, and deregulation. His main point is what he calls the "historical fact" that the now developed countries, during their own historical processes of growth and development, used virtually none of these. His second point is that this package of policies amounts to "kicking away the ladder" and prevents contemporary developing countries from promoting industrialization, technological acquisition, and upgrading.

Wade (2003) agrees that developing countries are now more "tightly constrained in their national development strategies by proliferating regulations formulated and enforced by international organizations" (p. 621). The most contentious policy is that of trade-related investment measures (TRIMs), which emerged from the Uruguay Round of GATT-WTO trade negotiations in the mid-1990s. The TRIMs policy aspires to "avoid trade and investment distortions" which, argue Chang and Wade, prevents the governments of developing countries from deliberately distorting the policy framework to promote investment and technological absorption by firms located within the domestic economy.

These concerns are overstated. TRIMs prohibit measures that (i) require particular levels of local sourcing by an enterprise, (ii) restrict the volume or value of imports that an enterprise can buy/use to the volume or value of products it exports, (iii) restrict the volume of imports to the amount of foreign exchange inflows attributable to an enterprise, and (iv) restrict the export by an enterprise of products or a proportion of the volume/value of local production (Di Caprio \& Amsden, 2004). This list of restrictions leaves open various other "safeguards" that can be used by contemporary developing countries to promote industrialization and technology acquisition.

Developing countries can support their own industries, target national champions, and advance general national competitiveness in the name of "promoting science and technology." A wide range of subsidies is still permitted in research and development (including innovation, technological upgrading, and venture financing), disadvantaged subnational regions, and environmental upgrading (Weiss, 2005). The main constraint is not international law but domestic politics: "the most coercive part of the new international economic order is informal" (Amsden \& Hikino, 2000, p. 110). Rarely do contemporary developing countries (certainly including Pakistan) have a political faction capable of articulating and promoting creative industrial policy and of going beyond the mantra "the more liberalization, the better." 


\subsection{Global Value Chains}

A key factor determining the structure of the global clothing and textiles sector is the concentration of global buying power in the developed countries. There has been a massive increase in market concentration among retailers in the developed countries. Even by 1995, Wal-Mart, Sears, Kmart, the Dayton-Hudson Corporation, and JC Penney accounted for 68 percent of all apparel sales in the US. This process has influenced the prospects for exports and upgrading in Pakistan in various ways. Such buyers require large volumes and low prices, making it difficult for small suppliers (typical of Pakistan) to meet their requirements. Instead, this has benefited large Chinese suppliers. The demand for shorter lead-times, greater inter- and intra-seasonal variety, and tighter delivery logistics typical of highly competitive world markets makes it harder to enter a value chain without an established production reputation. The profitability of being a producer in such a value chain is, therefore, tightly constrained.

Since the 1990s, there has been a downward trend in the global price of clothing as reflected in the unit price of clothing imports into the US (Kaplinsky \& Morris, 2008). This has combined with ever more demands beyond simple assembly being pushed onto producers by the buyers, including contributions to product design, fabric sourcing, inventory management, and management of production sourcing. Textiles is typically a buyer-driven chain whereby those large retailers and branded manufacturers outsource production but retain control of access to the major resources (such as product design, new technologies, brand names, consumer demand) that generate the most profitable returns-and so, constrain efforts to upgrade (Gereffi \& Memedovic, 2003).

Taiwan established textile production in the 1950s with hundreds of small firms. In this earlier era, low labor costs was the key to being globally competitive. The subsequent rise of global value chains has meant that constraints to participation in the industry have increased, but this process has also supplied the means by which determined countries can do so. Today, retailers and marketers in developed countries tend to rely on full-package sourcing networks and buy readymade apparel from East Asia. As wages have risen in East Asia, low-wage assembly is carried out in third countries' regions. East Asian manufactures have moved to being intermediaries in value chains that include 50-60 exporting countries. These intermediaries may squeeze developing country 
producers hoping to enter a global value chain but, crucially, they can also help facilitate that entry.

Once part of a global value chain, history has shown that local entrepreneurs can learn the preferences of foreign buyers and international standards for price, quality, and delivery and so develop substantial linkages to the domestic economy and develop production expertise over time. This potential broadening of the supply base is something Pakistan could work to its advantage.

It is also important not to think of global value chains as a single and uniform global process. Too often, survey evidence from the US or UK markets is used to generalize global trends. In various European countries, the state has used the law to restrain the power of retailers in order to promote more equitable relations between them and product suppliers. Based on fieldwork studies in the early 2000s, Palpacuer et al. (2005) find that buying was far more dispersed in French than British sourcing networks and that UK firms had rationalized their supply base much more than had French and Scandinavian firms. In Scandinavia, the limited extent of supply base rationalization indicates a more informal system of relations with suppliers. French firms did not insist that new suppliers offer all the extra production services (as noted above) and there was greater ease of entry and upgrading opportunities for developing country producers in French networks. This implies that there do remain easier market niches in developed countries to which firms from developing countries can gain access.

\subsection{The Problem of Energy and Education in Pakistan}

Pakistan has suffered an ongoing energy crisis since 2007. Unannounced power outages in some cities have reached up to 18 hours at a time. Siddiqui et al. (2011) have conducted a survey of 339 firms in four major industrial cities of Punjab (Gujarat, Faisalabad, Gujranwala, and Sialkot). Over 52 percent of firms in the textiles sector reported losing more than three labor-hours per day. Almost 76 percent of the total firms had opted for alternative energy arrangements (mostly standby generators); 85 percent of them argued that this had increased production costs by an average of 26.5 percent. Some 67.5 percent of textile firms confirmed delays in supply orders. Overall, textile firms reported losing 22 percent of their output. There is no question that this energy crisis must be addressed for the entire industrial sector to competitively produce, export, and upgrade. Importantly, however, the energy crisis is not the root cause of the 
"historical failure" of the textiles sector in Pakistan. As Section 2 has shown, this failure was evident long before the energy crisis emerged.

A significant constraint to Pakistan's ability to break away from its dependence on low-skill, low-technology manufactured exports is the country's poor state of human capital. In 2003/04, 48 percent of the population aged 10 years or above was illiterate, including 60 percent of females (Khan, 2009). There are not just concerns with the lack of quantity in education but also with quality. The 2003 Learning and Educational Achievement in Punjab Schools (LEAPS) project survey generated test scores in three subjects for over 12,000 children and combined test scores and child characteristics for 6,241 children. At the end of grade 3, a bare minimum had mastered the mathematics curriculum for grade 1 and less than 20 percent could understand a simple written sentence in the vernacular. Less than 10 percent could graphically represent simple information (bar charts) compared to more than 70 percent internationally. "Close to one half of the three million born in Pakistan will leave school unable to add, subtract, multiply or divide, unable to read and write simple sentences in Urdu; and unable to read a short word like "BALL" in English" (Das, Pandey, \& Zajonc, 2012, p. 232).

The main factor is schooling, not household, characteristics. It is primarily a problem of school availability and quality, not of social inequalities. The adjusted gap between public and private schools in English is 12 times the adjusted gap between rich and poor children; the adjusted gap between public and private schools in mathematics is eight times the adjusted gap between children with literate and illiterate fathers. Pakistan also fails with regard to vocational education. By the mid-2000s, it had 3,125 technical and vocational institutions with a total enrolment of 256,000 . The curriculum had little relevance to the changing skill needs of the labor market and there was minimal hands-on training.

Outcomes were equally bad in the 70 percent of such institutions based in the private sector. The oldest polytechnic institute, the Government Polytechnic Institute in Karachi, offered training in 17 different trades, but by mid-2009 was in a state of disrepair (Khan, 2009). Pakistan has increased its school enrolment slower than countries with comparable GDP growth and has a lower level of enrolment than countries with similar levels of income (Birdsall, Ross, \& Sabot, 1993; Easterly, 2001).

There is no question but that the state of education must be improved. Not only does poor-quality education constrain exporting and 
upgrading, it is also a vital part of what constitutes the good society. The problem is the time-scale. It is not easy to change the education system, marred as it is by poor attendance, poor facilities, and absent teachers. My own university, after nearly 800 years, has still not achieved parity across genders and ensured equal access for poorer students. Reforms are, of course, needed but improved education is unlikely to be part of any policy-driven solution for textiles in the immediate future.

\section{Technology and Learning}

This section problematizes a typical form of economic "analysis" in Pakistan: that of producing long lists of problems and urging policymakers to solve them. The second part focuses on a key market failure: that of technology acquisition and learning. Finally, we explore some potential solutions accounting for prioritizing reform, the feasibility of reform, and learning applicable lessons from elsewhere.

\subsection{Prioritizing Reform}

There is a tendency among both consultancy organizations and the Government of Pakistan to produce long lists of problems, urge their "solution," and call this a serious analysis and agenda for reform. Rarely is there any attempt to prioritize reform, learn from reform efforts elsewhere, or consider the feasibility of reforms in the Pakistani context.

The first example from consultants is that by the Competitiveness Support Fund (2010), a report financed by the United States Agency for International Development. In its evaluations of the country's economic competitiveness, Pakistan scores poorly on security (terrorism, organized crime, the business costs of crime and violence, and the reliability of the police services), infrastructure (especially energy), health and education (primary, higher, and training), and the business environment (international distribution networks, supplier quality). In response, the report argues that a "comprehensive institutional reform program is vital to Pakistan's competitiveness strategy" (p. 62).

This is no clearly articulated strategy in terms of a practical plan for policy action but rather a bewildering and overwhelming list of desirable outcomes. Aspects of this "comprehensive strategy" include "working with Pakistan's leading export industries to remove obstacles to competitiveness, lower cost of inputs, enhance efficiency of trade logistics, increase productivity and introduce innovative technology" (Competitiveness Support Fund, 2010, p. 43); modernizing the financial 
sector; ending electricity shortages; improving infrastructure; improving education and training; commercializing research in Pakistani universities; and creating an effective security and police system that reduces the cost of doing business.

Another example, this time from the government, is the Framework for Economic Growth (Pakistan, Planning Commission, 2011). The report contains a familiar litany of aspirations posing as policy advice: to "strive for institutions that support free and fair markets, create a professional, well trained civil service" (pp. 17-18), "developing physical and regulatory space for entrepreneurial and innovative investments" (p. 27), "governance and institutions reforms are required" (p. 41), and "a focused effort will be required in areas such as science and technology, attracting talent and investment, venture capital and education policies that promote enterprising talents" (p. 56). In the appendix to the report (pp. 136-144) are listed the short-term policies that should be achieved within a year. These include restructuring public enterprises, rationalizing subsidies, amending zoning laws and building regulations, establishing a regulatory body for the real estate market, enforcing rules and regulations in energy provision, and enhancing literacy.

Beyond their mania for lists, this type of approach ignores what we can learn from history in two ways: first, the history of institutional change and, second, the relation between economic growth and institutional change.

First, the possibility of the rapid institutional change advocated in these reports is contradicted by the historical experience of today's developed countries. Now-developed countries experienced, according to Chang (2003), a "long and winding road" of institutional development that took "decades." From full male to universal suffrage, it took France from 1846 to 1946 and Switzerland from 1879 to 1971. The need for a modern professional bureaucracy in Britain was first mooted in the eighteenth century and became a reality only in the early nineteenth century. Such slow change was often because of widespread realization that many changes were expensive (labor laws and social security), resistance from those who would lose out (democracy, income tax), the absence of supporting changes (the tax revenues needed to pay for a professional bureaucracy), or prejudice (female suffrage) (Chang 2003).

Second, in historical terms, "good institutions" have tended to follow, rather than been a precondition for, rapid economic growth, 
industrialization, and upgrading. Khan (2002) notes that the indices of institutional quality (based on the quality of bureaucracy, the rule of law, expropriation risk, and contract repudiation) among East Asian governments were, as late as the mid-1980s, only slightly better than those of many poor-performing countries. Fast-growing Indonesia scored the same as Myanmar or Ghana, and the Republic of Korea, Malaysia, and Thailand the same as Cote D'Ivoire. The corruption index created by Transparency International shows that, for 54 countries between 1980 and 1990, the rapidly growing East Asian countries had corruption scores that were little different from those of other developing countries (Khan, 2002).

There is much broader evidence to show that now-developed countries also had poor institutions during their initial transition to rapid growth (Chang, 2002). At a similar stage of development, the nowdeveloped countries were much less institutionally advanced. The UK in 1820 had a broadly similar per capita income to India today, but did not have many of the latter's present-day institutions and organizations, including universal suffrage, a central bank, income tax, generalized limited liability, a modern bankruptcy law, a professional bureaucracy, and securities legislation (Chang, 2003).

The approach in this paper is to suggest a small number of feasible policy interventions that could be made in the textiles sector, recognizing the domestic political and administrative constraints within Pakistan and drawing on lessons from similar developing countries.

\subsection{Identifying the Constraining Market Failure: Technology Acquisition and Learning}

Catch-up requires sustained and rapid productivity growth and this depends on the creation of new technologies. Despite very low wages in developing countries and being freely able to buy machinery and equipment in international markets at virtually the same price as in advanced countries, developing countries find few areas in which they can achieve global competitiveness. Low wages do not compensate for the very low initial productivity of developing countries, even in lowtechnology sectors. Productivity is determined by much more than access to technology. In the nineteenth-century textiles industry, most key industrial technologies were able to diffuse quite rapidly as Britain had developed a specialized export-oriented machine-building sector within its cotton industry; by 1845, some of these firms were exporting at least 50 percent of their production. These firms provided a complete package of services to customers, including technical information, machinery, 
construction expertise, managers, and skilled operatives (Wolcott \& Clark, 1999; Clark, 2007).

Having access to this same technology in Japan nearly trebled its output per worker between 1907 and 1935, while India showed no change over the same years (Clark, 2007, p. 347). India failed to efficiently utilize this basic technology and Indian mills employed up to five times the number of workers needed (p. 363). There are other more recent examples. Productivity was four times greater in Mauritius than Ghana, using similar production technology in manufacturing; for large firms, wages were only three times as high. This combination gave Mauritius a significant competitive advantage (Teal, 1999). Thai firms produce three times as much value-added from given capital and labor in the textiles and food-processing industries than do Kenyan firms in the same industry (Zuefack, 2001).

There is good evidence that the problem in Pakistan is with using existing capacity (productivity), not with a lack of capacity (investment). There is no obvious constraint to meeting any extra demand. In the cotton-spinning sector in 2011, capacity utilization was 89 percent in spindles and 60 percent in rotors. Low rates of capacity utilization were also characteristic of automobiles, cement, and fertilizer. Table 2 below shows that (in the jute industry) between 2011/12 and 2012/13, there were small increases in the number of spindles and looms installed but significant falls in the number of spindles and looms actually worked.

Table 2: Installed and working capacity in jute

\begin{tabular}{lrrr}
\hline & $\mathbf{2 0 1 1 / 1 2}$ & $\mathbf{2 0 1 2 / 1 3}$ & \% Change \\
\hline Spindles installed & 36,087 & 36,172 & 0.24 \\
Spindles worked & 24,279 & 21,836 & -10.06 \\
Looms installed & 1,852 & 1,856 & 0.22 \\
Looms worked & 1,021 & 940 & -7.00 \\
\hline
\end{tabular}

Source: Pakistan Economic Survey 2012-2013, p. 41.

Low productivity can be explained by inadequate knowledge of modern production techniques and activities such as modern factory layout management, inventory management, sales, and servicing (Khan, 2008). Much of the technological and organizational knowledge necessary for competitiveness is tacit, embedded in routines. Effective production requires a mix of formal or codifiable (that which can be communicated 
in words/symbols) and uncodifiable knowledge (embedded in unconscious and often complex routines) (Khan, 2013a). Unlike investment, which expands existing production or replicates well-known technologies, new technologies have an unknown payback period and, therefore, carry a higher degree of risk and uncertainty. It takes time to experiment and integrate new machines into production in an optimal manner; the mechanism for learning to improve actual production processes is through learning-by-doing.

The key market failure is, therefore, a financing problem: the period of risk and loss making that has to be financed while learning-by-doing is taking place. Own-investment by the firm will be limited to the availability of retained profits and the owner's willingness to undertake the risk. In theory, private investors could be lured by the prospect of future profits and finance that loss making. In reality, this rarely happens. Private investors are happy to finance investment in known sectors where the market is assured, the methods of production standardized, and the payback period clearer. In Bangladesh, for example, survey evidence shows that there is no shortage of bank finance that is readily available for established technologies and entrepreneurs (Khan, 2008). In the World Bank's (2007) Enterprise Survey, only 17.7 percent of Pakistani firms surveyed reported access to finance as a major constraint, compared to 33.4 percent in other South Asian countries and 29.7 percent across 135 countries.

Learning to utilize new technology to raise productivity requires significant effort by managers, workers, and suppliers (Khan, 2011). A firm could contract with a bank to supply this requisite effort in return for lending and repay the loan from future profits. Accurate disclosure of profits and enforcing the rights of outside investors (such as banks or shareholders) is difficult to ensure in a developing-or even developedcountry. In theory, enforcing the rule of law, reducing corruption, and increasing transparency can ensure the enforcement of such contracts but (as noted in Section 4.1) this is likely to take a long time.

In Bangladesh, survey participants were asked about the mechanisms by which good governance reforms might solve their problems-such as a more efficient stock market allowing them to raise funds. Participants "universally agreed that these conventional mechanisms were implausible even in the medium term" (Khan, 2008, p. 21). In Pakistan, less than 1 percent of firms in 2007 financed investment by equity or stock sales (World Bank, 2007). In practice, banks try to protect themselves by requiring high-quality collateral and high interest 
rates from borrowers, which passes on the risk from the bank to an entrepreneur-owner. Survey evidence in Bangladesh confirms this, showing that firms were concerned about the high levels of interest rates even for loans backed by good collateral, the combination of which shifted the risk of delay and problems with new technology to the borrower (Khan, 2008).

\subsection{Solutions to the Learning Failure}

One solution would be to directly subsidize the cost of acquiring technologies. The 2005/06 budget in India proposed investing US\$ 700 million in apparel parks, cluster development, cotton procurement, health and insurance, and upgrading technical skills. The resulting Technology Upgradation Fund covered all manufacturing segments of the textiles industry and encouraged the private sector to set up world-standard integrated textile complexes and processing units. The fund aimed to provide 50,000 shuttle-less looms for the sector and modernize 250,000 power looms in the decentralized sector. Under the fund, manufacturing firms became eligible for long- and medium-term loans from state banks at an interest rate 5 percent lower than the normal bank lending rates. Imports of textile machinery items and raw materials and parts for the manufacture of such machinery were permitted at concessional customs duty to reduce the cost of production.

In Pakistan, the Textiles Policy 2009-14 produced by the Ministry of Textiles was a similar effort, though much broader in scope. The policy recognized many of the constraints faced by the textiles industry: inadequate infrastructure facilities; the absence of exclusive areas dedicated to textiles production and provided with key services such as power, gas, and clean water; the lack of skilled labor; and the fact that the regulatory framework increased the cost of doing business.

True to the habit in Pakistan of making long lists of solutions in response to a long list of problems, the plan had no focus. It was less a plan than a long list of aspirations: to "develop state-of-the-art infrastructure facilities;" to "increase the supply of efficient human resources;" to "evolve a legislative framework that sets standards for each stage of processing" with a view to "increasing productivity," "improving quality," and "ensuring optimum utilization of resources;" to "promote $\mathrm{R}+\mathrm{D}$ " to "achieve product diversification," "technological advancement," and "increased productivity throughout the value chain," specifically in the "quality and diversity of fibers;" to support the 
"development of allied industry such as machinery manufacturing, dyes, and chemical industry and accessories" for "reducing the cost of doing business;" and to "encourage exports by meeting the demands of competition, technology and higher labor productivity."

This effort was costed at US\$ 8 billion (largely for the private sector) over five years and a government-provided "textiles investment fund" was promised. Areas for government funding were to include the modernization of machinery and technology, the removal of infrastructure bottlenecks, skills enhancement, better marketing, and the use of information technology. The funding was all-purpose to encourage manufacturers in all subsectors to modernize their machinery and technology. This aim did not target the key market failure in the risk associated with learning and technology acquisition. Funding was not targeted at risk but at "reducing the cost of financing to international level and ensuring adequate availability of credit for such purposes." Support was also promised "to attract joint ventures, mergers and FDI [foreign direct investment] for expansion and upgrading in the sector." The policy subsequently fizzled out in response to budget cuts and IMF pressures to reduce public spending.

A second solution would be to target incentives more closely to the mechanics of the learning failure. A firm could obtain a rent ${ }^{1}$ such as a subsidy or cheap credit that would allow it to engage in learning-by-doing. The conditions of rent withdrawal would need to be clear from the outset so that owners and managers felt compelled to put high levels of effort into learning (Khan, 2013b). This brings into question the balance of powerwhether the state has the capacity and willingness to allocate rents that are contingent on learning and to remove them in the event of failure.

In the 1960s in the Republic of Korea, technology was mainly transferred to large firms (chaebols) that received various forms of subsidy and protection from imports to give them an opportunity to expand production. Increased production was closely linked to learning-by-doing because such incentives were conditional on firms successfully reaching their export targets, reducing costs, and absorbing new technologies. The state maintained a credible threat to remove these incentives should firms fail to meet their targets. The balance of power between the state and the chaebols

${ }^{1}$ An economic rent can be defined as the proportion of earnings in excess of the minimum amount needed to attract a firm to enter a particular industry or produce a product using new methods of organization/technology. 
was such that inefficient firms were not able to protect their subsidies if the state decided to withdraw them (Khan \& Blankenburg, 2006).

Pakistan pursued a very similar economic strategy in the 1960s, although it was ultimately unable to attach performance conditions to subsidies and large firms were able to form alliances with powerful political factions to prevent subsidies being reallocated once given. Too often in Pakistan, analysis stops here, compares Pakistan to the Republic of Korea and argues that it should try and emulate the latter; that Pakistan should try and recreate the political conditions that supported such successful policy interventions.

For the Republic of Korea, those successful preconditions are usually framed in terms of it having been a "developmental state." A developmental state is defined as "states whose politics have concentrated sufficient power, autonomy and capacity at the centre to shape, pursue and encourage the achievement of explicit development objectives, whether by establishing and promoting the conditions and direction of economic growth, or by organizing it directly, or by a varying combination of both" (Leftwich, 1995, p. 401). There are six components that determine these political preconditions. These include (i) a small elite of developmentally determined senior politicians, (ii) the autonomy of the state from special interest groups, (iii) a competent bureaucracy insulated from the demands of politics, (iv) a weak civil society, (v) independence from international capital and rural interests, and (vi) the popular legitimacy given to a singleminded approach to economic growth. This is not going to happen in Pakistan, so any comparison with, and especially calls to emulate, the Republic of Korea are nonsense (Leftwich, 1995).

A more reasonable comparison is with Bangladesh. In 2005, the country tied for bottom place (with Chad) in Transparency International's ratings of corruption. This did not prevent Bangladesh from adopting fairly reasonable economic policies and growing. By 2010, RMG exports totaled US\$ 16 billion and provided 82 percent of Bangladesh's total merchandise exports. Since 2005, clothing exports have grown at an average annual rate of 25 percent, despite concerns that the end of the MFA quota system would undermine Bangladeshi exports.

Ahmed, Greenleaf, and Sacks (2014) ask how effective industrial policies can be pursued with weak governance institutions, widespread corruption, and an intensely politicized policymaking process. Neither of the two main political parties in Bangladesh (the Bangladesh Awami 
League and Bangladesh Nationalist Party) has a clearly defined economic platform nor campaigns on distinct policy agendas. Both parties maintain large enough coalitions of support to remain in power via the redistribution of the spoils of office. The parallels with the Pakistan People's Party and Pakistan Muslim League (PML-N) are evident where ideology has been off the agenda since the 1970s. For both parties in Bangladesh, these coalitions increasingly comprise legislators with financial stakes in the RMG sector. Despite the two main parties alternating in power, economic policy has remained consistent: both parties favor liberalization, privatization, and export-led growth. Again, the parallels with Pakistan are evident. The incoming PML-N government in 2013 had no aspirations to change the broad thrust of policy in Pakistan, only to pursue the liberalization agenda more competently.

So, it is to Bangladesh that policymakers in Pakistan could turn for policy learning. The state in Bangladesh has decentralized and delegated responsibility to private organizations such as the Bangladesh Garment Manufacturers and Exporters Association (BGMEA) and the Bangladesh Knitwear Manufacturers and Exporters Association. The government's decision to delegate authority to the BGMEA to issue trade (import) customs certificates (utility decision and preparation) streamlined the process by which garment manufacturers acquire imported raw materials and technology. To facilitate export financing without government subsidies, the government implemented a back-to-back letter of credit (L/C) system in 1986/87 that made it easier to acquire working capital for garment manufacturers. The system works in a way that does not require garment manufacturers (or the government) to invest money to open import L/C or make payments to the fabric suppliers from their own resources.

This system is not vulnerable to the budget constraints that undermined the 2009 textiles policy in Pakistan. The operation of the back-to-back L/C system assured garment exporters of almost 70 percent of the working capital they needed. Most RMG exporters agree that the $\mathrm{L} / \mathrm{C}$ is the most important factor responsible for the rapid growth of garment exports in Bangladesh (Ahmed et al., 2014).

Even with a wage/cost advantage, Bangladesh did not break into the garments business without a number of critical financing accidents that allowed it to build the capabilities that launched the industry. This demonstrates that even a labor-intensive and low-technology activity can require a period of learning-by-doing (Khan, 2011). The MFA post-1973 set bilaterally negotiated quotas on developing countries for textile and 
clothing exports mainly to satisfy US producers threatened by cheap imports. Bangladesh was not initially included in the MFA, which created incentives for multinationals to set up garment production units in Bangladesh as a base for exporting to developed countries.

The Korean firm Daewoo set up Desh garments in 1979 with a domestic entrepreneur providing the capital for investment in plant and machinery. The collaboration between Desh and Daewoo was initially scheduled to run for five years. Desh workers were provided six months' training in Korea. Desh also purchased machinery from Daewoo and managed production with supervision/marketing by Daewoo. Desh was to make royalty payments to Daewoo for the technical training and supervision equal to 3 percent of its sales and pay sales commission for marketing services.

The Desh workers at the Pusan plant received some of the most intensive on-the-job training in garment production ever seen in the history of developing countries (Rhee, 1990, p. 337). The training provided actual experience of running a factory that produced worldquality exportable goods. Everyone had strong incentives and compulsions to expend high levels of effort on learning and capability building. Daewoo had strong incentives to push knowledge and capabilities as the fastest way to recover its investment. Desh employees had strong incentives to learn in Pusan-to ensure the firm would survive. Desh saw its average export values grow by 90 percent per annum in the 1980s. By the end of the 1980s, 115 of the 130 employees initially trained by Daewoo became entrepreneurs and set up their own factories. The migration of skilled workers/managers worked to create an industrial cluster that attracted buyers and created its own beneficial dynamic to drive growth in the sector (Khan, 2011).

Pakistan cannot, in 2014, replicate those peculiar features of the quota rents created by the MFA at the end of the 1970s, but it can learn from that experience. Increased learning needs new financial institutions that specialize in providing long-term finance at low interest rates to finance technology acquisition and subsequent learning-by-doing. These financial instruments can be designed to replicate the incentives and compulsions faced by Desh in 1979. A well-designed financing instrument for technology upgrading should be able to pool the risk so that an individual firm would not face bankruptcy if a project to upgrade technology takes longer than planned. Such an instrument should also create sufficient incentives for the owner/manager to put in significant effort, and finally set a satisfactory rate 
of return for outside investors. Given the problems of ensuring the accurate disclosure of financial and profit data, a viable risk-sharing financial instrument in Pakistan should rely on easily observable proxy indicators to assess profit and asset values indirectly.

Export earnings are relatively easy to observe. Banks in Bangladesh have long-standing arrangements that deduct the interest due from export earnings. As the garments industry in Pakistan is largely export-oriented, this rule would achieve effective profit sharing based on an easy-to-monitor income stream rather than profit disclosures by firms. Payments based on export earnings mean that firms would only start to repay a loan once they had mastered the new technology sufficiently to begin exporting.

The second requirement is that the design of the instrument should compel the borrower to acquire the technology needed as rapidly as possible. The initial loan from the bank would take the form of an equity share in the textile company, which would entitle the bank to a profit share for as long as it held that share. The firm would, over time, be able to repay the bank and so buy back its claim on the company's assets. There would have to be an effective increase in the buyback value to reflect growth in the value of underlying assets due to successful technology adoption and adaptation. A possible solution would be to agree in advance to a moderate rate of increase in the underlying asset value, which would create pressure on the firm to buy back the equity quickly without making the investment excessively risky (Khan, 2008).

\section{Conclusion}

The textiles industry in Pakistan has failed to fulfill its "historical mission." It has failed to lead a wider process of rapid economic growth, to reduce poverty, to provide empowering employment for young women, and to act as a conduit for the introduction of technology into Pakistan. The promising momentum of the 1960s was not sustained. The 1970 s to 1990s were associated with continued growth but also a continued failure to realize these wider benefits. Most recently, the promise of new market access to the EU has stirred some optimism, but a brief examination of the AGOA program of the early 2000s shows how quickly the gains from any preferential market access can unravel if that access is not accompanied by real improvements in productivity. 
There is widespread awareness and even consensus surrounding what is wrong with textiles. Unfortunately, this has produced a particular kind of "analytical" response: to list all the various problems in Pakistan's economy, in particular those factors doing badly in relation to other developing countries, and to then advocate their "reform" and "improvement" and pass this off as serious policy advice. This produces no practical guide for policymakers or the means to prioritize their scarce administrative capacities. Rather, it overwhelms them with the scale of the task, producing a sense of cynical hopelessness.

This paper makes a case for a particular and targeted form of industrial policy to promote learning and upgrading in the textiles industry. It has argued that those factors commonly seen as hindering industrial policy-the China effect, the global rules of globalization, global value chains, and the problems of energy and education-do need careful consideration but are not insurmountable obstacles to industrial upgrading. The paper then goes on to make a case for key market failure: that of the risk and uncertainty associated with acquiring and learning to use new technology. It explores a number of policy options, reviewing the lessons that cannot be learned from the Republic of Korea and India and one that can from Bangladesh. The latter shows that rapid and sustainable export growth in textiles can be achieved, even in an economy with weak, corrupt, and unstable governance. 


\section{References}

Agrawal, P., \& Sahoo, P. (2003). China's accession to WTO: Implications for India and China. Economic and Political Weekly, 38(25), 2544-2551.

Ahmed, F. Z., Greenleaf, A., \& Sacks, A. (2014). The paradox of export growth in areas of weak governance: The case of the readymade garment sector in Bangladesh. World Development, 56, 258-271.

Amjad, R. (1982). Private industrial investment in Pakistan 1960-1970. Cambridge: Cambridge University Press.

Amjad, R. (1983). Industrial concentration and economic power. In H. Gardezi \& J. Rashid (Eds.), Pakistan: The roots of dictatorship: The political economy of a praetorian state. London: Zed Press.

Amjad, R. (2005). Skills and competitiveness: Can Pakistan break out of the low-level skills trap? Pakistan Development Review, 44(4), 387-409.

Amsden, A. H., \& Hikino, T. (2000). The bark is worse than the bite: New WTO law and late industrialization. Annals of the American Academy of Political and Social Science, 570, 104-114.

Ananthakrishnan, P., \& Jain-Chandra, S. (2005). The impact on India of trade liberalization in the textiles and clothing sector (Working Paper No. 05/214). Washington, DC: International Monetary Fund.

Ara, I. (2004). Is Pakistan's manufacturing sector competitive? Pakistan Development Review, 43(4, Pt. 2), 685-706.

Birdsall, N., Ross, D., \& Sabot, R. (1993). Underinvestment in education: How much growth has Pakistan foregone? Pakistan Development Review, 32(4), 453-499.

Chang, H.-J. (2002). Kicking away the ladder: Development strategy in historical perspective. London: Anthem Press.

Chang, H.-J. (2003). Kicking away the ladder: Infant industry promotion in historical perspective. Oxford Development Studies, 31(1), 21-32.

Cheema, A. A. (1978). Productivity trends in the manufacturing industries. Pakistan Development Review, 17(1), 44-65. 
Clark, G. (2007). A farewell to alms: A brief economic history of the world. Princeton, NJ: Princeton University Press.

Collier, P. (2007). The bottom billion: Why the poorest countries are failing and what can be done about it. Oxford: Oxford University Press.

Competitiveness Support Fund. (2010). The state of Pakistan's competitiveness report 2010-2011. Islamabad: Author.

Das, J., Pandey, P., \& Zajonc, T. (2012). Learning levels and gaps in Pakistan: A comparison with Uttar Pradesh and Madhya Pradesh. Economic and Political Weekly, 47(26-27), 228-240.

Di Caprio, A., \& Amsden, A. (2004). Does the new international trade regime leave room for industrialization policies in the middle-income countries? (Working Paper No. 22). Geneva: International Labour Office.

Easterly, W. (2001). The political economy of growth without development: A case study of Pakistan. Paper prepared for the Analytical Narratives of Growth Project, Harvard University, Cambridge, MA.

Gereffi, G., \& Memedovic, O. (2003). The global apparel value chain: What prospects for upgrading by developing countries? Vienna: United Nations Industrial Development Organization.

International Labour Organization. (2012). Global wage report 2012/13. Geneva: International Labour Office.

Kaplinsky, R., \& Morris, M. (2008). Do the Asian Drivers undermine the export-oriented industrialization in SSA? World Development, $36(2), 254-273$.

Kemal, A. R., Din, M., \& Qadir, U. (2006). Economic growth in Pakistan. In K. S. Parikh (Ed.), Explaining growth in South Asia. New Delhi: Oxford University Press.

Khan, M. (2002, June). State failure in developing countries and strategies of institutional reform. Paper presented at the Annual Bank Conference on Development Economics, Oslo.

Khan, M. (2008). Technological upgrading in Bangladeshi manufacturing: Governance constraints and policy responses in the readymade garments industry (Mimeo). London: School of Oriental and African Studies. 
Khan, M. (2011). The economic development of Bangladesh: Identifying pragmatic policy responses. In M. Ullah (Ed.), Bangladesh tomorrow (pp. 11-68). Dhaka: Center for Sustainable Development.

Khan, M. (2013a). Technology policies and learning with imperfect governance. In J. Stiglitz \& J. Y. Lin (Eds.), The industrial policy revolution I: The role of government beyond ideology. London: Palgrave.

Khan, M. (2013b). Political settlements and the design of technology policy. In J. Stiglitz, J. Y. Lin, \& E. Patel (Eds.), The industrial policy revolution II: Africa in the twenty-first century. London: Palgrave.

Khan, M., \& Blankenburg, S. (2006). The political economy of industrial policy in Asia and Latin America. In M. Cimoli, G. Dossi, \& J. Stiglitz (Eds.), Industrial policy and development. Oxford: Oxford University Press.

Khan, N. Z. (1998). Textiles sector of Pakistan: The challenge beyond 2004. Pakistan Development Review, 37(4), 595-619.

Khan, S. H. (2009). Making people employable: Reforming secondary education in Pakistan. Pakistan Development Review, 48(4), 603-617.

Lall, S. (2000). The technological structure and performance of developing country manufactured exports, 1985-98. Oxford Development Studies, 28(3), 337-369.

Lall, S., \& Weiss, J. (2004). Industrial competitiveness: The challenge for Pakistan (Seminar Paper No. 2). Islamabad: Asian Development Bank.

Leftwich, A. (1995). Bringing politics back in: Towards a model of the developmental state. Journal of Development Studies, 31(3), 400-427.

Lewis, S. R. (1970). Pakistan: Industrialization and trade policies. London: Oxford University Press.

Mahmood, Z., \& Siddiqui, R. (2000). State of technology and productivity in Pakistan's manufacturing industries: Some strategic directions to build technological competence. Pakistan Development Review, 39(1), 1-21.

McCartney, M. (2011). Pakistan: The political economy of growth, stagnation and the state, 1951-2008. London: Routledge. 
Nathan Associates. (2009). Cost competitiveness of Pakistan's textiles and apparel industry. Washington, DC: United States Agency for International Development.

Pakistan, Ministry of Finance. (2013). Pakistan economic survey 2012-2013. Islamabad: Author.

Pakistan, Planning Commission. (2011). Pakistan: Framework for economic growth. Islamabad: Author.

Palpacuer, F., Gibbon, P., \& Thomsen, L. (2005). New challenges for developing country suppliers in global clothing chains: A comparative European perspective. World Development, 33(3), 409-430.

Pasha, H. A., Ghaus-Pasha, A., \& Hyder, K. (2002). The slowing down of the growth of total factor productivity in Pakistan (Research Report No. 44). Karachi: Social Policy and Development Centre.

Rhee, Y. W. (1990). The catalyst model of development: Lessons from Bangladesh's success with garment exports. World Development, 18(2), 333-346.

Siddiqui, R. H., Jalil, H., Nasir, M., Malik, W. S., \& Khalid, M. (2011). The cost of unserved energy: Evidence from selected industrial cities of Pakistan (Working Paper No. 2011:75). Islamabad: Pakistan Institute of Development Economics.

Srinivasan, T. N. (2005). Productivity and economic growth in South Asia and China [Distinguished Lecture]. Pakistan Development Review, 44(4), 479-503.

Talha, N. (2000). Economic factors in the making of Pakistan (1921-1947). Karachi: Oxford University Press.

Teal, F. (1999). Why can Mauritius export manufactures and Ghana not? World Economy, 22(7), 981-993.

Tewari, M. (2005). Post-MFA adjustments in India's textile and apparel industry: Emerging issues and trends (Working Paper No. 167). New Delhi: Indian Council for Research on International Economic Relations. 
Wade, R. H. (2003). What strategies are viable for developing countries today? The World Trade Organization and the shrinking of "development space." Review of International Political Economy, $10(4), 621-644$.

Weiss, L. (2005). Global governance, national strategies: How industrialized states make room to move under the WTO. Review of International Political Economy, 12(5), 723-749.

Wolcott, S., \& Clark, G. (1999). Why nations fail: Managerial decisions and performance in Indian cotton textiles, 1890-1938. Journal of Economic History, 59(2), 397-423.

World Bank. (2007). Pakistan: Enterprise survey 2007. Washington, DC: Author.

Zaidi, S. A. (2005). Issues in Pakistan's economy (2nd ed.). Karachi: Oxford University Press.

Zeufack, A. (2001). Export performance in Africa and Asia's manufacturing: Evidence from firm-level data. Journal of African Economies, 10(3), 258-281. 